Article

\title{
Coffee, Migration and Climatic Changes: Challenging Adaptation Dichotomic Narratives in a Transborder Region
}

\author{
Celia Ruiz-de-Oña ${ }^{1, *} \mathbb{C}$, Patricia Rivera-Castañeda ${ }^{2}$ and Yair Merlín-Uribe ${ }^{3}$ \\ 1 Multidisciplinary Research Center on Chiapas and the Southern Border (CIMSUR), National Autonomous \\ University of Mexico, Calle Ma. Adelina Flores \# 34-A, Barrio de Guadalupe, \\ San Cristóbal de Las Casas C.P. 29230, Mexico \\ 2 Departamento de Estudios Urbanos y Medio Ambiente, Colegio de La Frontera Norte, Tijuana C.P. 22560, \\ Mexico; privera@colef.mx \\ 3 Department of Agriculture, Society and Environment, El Colegio de la Frontera Sur (ECOSUR), \\ Carretera Panamericana y Periférico Sur S/N, Barrio María Auxiliadora, San Cristóbal de Las Casas, \\ Chiapas C.P. 29290, Mexico; yairmerlin7@gmail.com \\ * Correspondence: celiardo@unam.mx; Tel.: +52-967-672-0538
}

Received: 3 September 2019; Accepted: 15 November 2019; Published: 25 November 2019

\begin{abstract}
The narratives of migration as adaptation and in situ adaptation are well established in mainstream adaptation policy and are usually presented as independent and opposing trends of action. A common and fundamental element of such narratives is the depoliticized conception of both migration and adaptation. Using a trans-scalar approach, we address the migration-coffee-climate change nexus: first at a regional scale, at the conflictive border of Guatemala-Mexico, to show the contradiction between the current Central American migratory crisis and the narrative of migration as adaptation; second, at a local scale and from an ethnographic perspective, we focus on the process of in situ adaptation in shade-grown coffee plots of smallholder coffee farmers in the Tacaná Volcano cross-border region, between Chiapas and Guatemala. We argue that the dichotomy "in situ adaptation" versus "migration as adaptation" is not useful to capture the intertwined and political nature of both narratives, as illustrated in the case of the renovation of smallholders' coffee plots in a context of climatic changes. We provide elements to contribute towards the repolitization of adaptation from an integral perspective.
\end{abstract}

Keywords: migration-climate change-coffee nexus; migration as adaptation; in situ adaptation; coffee leaf-rust; transborder region; narratives

\section{Introduction}

In the field of adaptation and its relation to the migration-climate change nexus, one of the most frequent and debated issues is the notion of migration as an adaptation strategy. It implies that migration can be considered —and encouraged —as a viable strategy for coping with the impacts of climate change, mainly due to climate disasters (Black et al. 2011). It is further argued that local development strategies linked to the notion of in situ adaptation have proven to be ineffective (Foresight 2011, p. 24). Alternatively, migration as adaptation has been presented as a failure of adaptive capacity in specific territories (Gemenne and Blocher 2017; Bardsley and Hugo 2010). Both notions-migration as adaptation and in situ adaptation-seem to be approached in mutually exclusive terms or at least in terms disconnected from each other. This paper argues that this dichotomous perspective has limitations in addressing and understanding the complex political nature of the adaptation-migration 
nexus and the multiple forms and expressions that the intersection of migration and climate change reveals in specific contexts.

In this article both notions, conceived as depoliticized narratives (Klepp 2017), are put into play in the particular context of the southern border of Mexico and from the perspective of the problem of coffee production in Mesoamerica (Central America and Chiapas, Mexico).

We focus on the crisis that the outbreak of the fungus Hemileia vastatrix, known as coffee leaf rust, has caused since 2012 as well as its complex interactions with the phenomenon of migration in the context of climatic changes. Because of the amplitude and virulence of the outbreak, coffee farmers in Central America and Chiapas were confronted with the necessity to conduct a deep renovation of coffee plants. The high-quality Arabica coffee varieties were no longer apt for cultivation at altitudes that before thrived well. Diverse institutional actors, national and international, were supporting this process that took different expressions according to political and local conditions.

However, migration rocketed in some countries where institutional support was absent or feeble, such as Guatemala or Honduras. Crops failure, violence, poverty and climatic changes merged into a cocktail that unleashed massive migrant movements that were partially deterred at the southern border of Mexico, due to the new immigration policies pushed from the United States.

The resulting migratory crisis (Isacson et al. 2014) offers an opportunity to analyze and jointly address the concept of migration as a form of adaptation put forward from mainstream adaptation practice and its interplay with those adaptive strategies on the ground-in situ adaptation-that seek precisely to curb migration.

To illustrate such interplay, we selected an emblematic coffee-producing region, the transborder Tacaná Volcano area, where we explored, in three communities at different altitudes, the process of adapting smallholders' coffee plots to the new climatic and producing conditions. We registered subjective narratives that evaluated how the government program for coffee renovation unfolded and the drawbacks that jeopardize a successful adaptation. Then, the role of national internal migration and international emigration to the Unites States was brought into the analysis.

The objective of the paper is to show the limitations of both approaches in capturing the fundamental political nature that underlays the adaptation practice and the interactions with the migratory phenomenon. What form do these interactions take for our case study? What are the implications of conceiving "migration as adaptation" as opposed to "in situ adaptation"? What lessons can it teach us regarding conceptions of migration and adaptation that do not recognize the political dimension that largely determines the future success of adaptation strategies?

To address these questions, we portray the multiple facets of migration, climate change and adaptation and their interweaving at different scales-following the suggestion of Eklund et al. (2016) in which scale issues are critical to present a rich and integrated understanding of the complexity attached to the migration phenomenon.

We maintain that the dichotomization of both streams of action simplifies and leaves unaddressed the web of causes and effects on which the migration-climate change nexus is continually being recreated. This is illustrated in our case study.

The ultimate purpose of the paper is to provide elements that contribute towards the repoliticization of adaptation practice and research (Klepp 2017), that pose new counternarratives enrooted in the political realities we face and, from there, to design adaptation strategies under a more integrated light, away from dichotomic options.

Such an approach has not been addressed in the academic literature dealing mainly with capacity adaptation of coffee systems in Chiapas (c.f. Frank et al. 2011; Götz et al. 2009) in which migration, although present, is not the analytical focus. The only study that tackles the nexus of migration-adaptation-coffee is that also conducted for the southern border of Mexico by Ruiz Meza $(2010,2015)$. 
However, studies dealing with the tension of migration as adaptation and in situ adaptation are lacking. This article seeks to fill this gap and motivate further discussion to strengthen the analytical nexus of migration-coffee-climate change.

The paper is structured as follows: first, we present a regional overview of the migration crisis in our area of study, a coffee-growing region, and the point of entry for Central American migratory caravans that intersect with local migratory flows. We highlight the connection between migrant caravans and the coffee crisis in which the issue of climate change is gaining presence. In a context of increasing militarization and enforcement of border control, we seek to evidence the mismatch between the narrative of migration as adaptation and the migratory crisis of Mexico's southern border.

Second, to provide a political economy view of the context in which coffee cultivation develops in our region of study, we present a descriptive statistical profile of macro factors, such as coffee productivity and demographics, at the level of the state of Chiapas and at the municipal level, which have repercussions on the communities of study. On this, we follow the recommendation offered by Gemenne and Blocher (2017), according to which an examination of recent changes in migration patterns should be a starting point of research in specific contexts.

Third, at the community level, we present ethnographic notes on local perspectives and experiences in migration and coffee farming as a way of life, trying to decipher those micro factors that add knowledge towards a more integrated view of the way migration is understood by locals and how it interferes with adaptation in the face of climatic changes.

The findings based on our case study reveal how political and economic constraints largely determine the success or failure of adaptation strategies. The case also reveals how the narrative of migration as adaptation does not make much sense in the case of coffee production, in which climatic and environmental factors aggravate population expulsion factors in territories that were largely shaped by waves of migrants. Findings also illustrate the inadequacy of the dichotomy "migration as adaptation" and "in situ adaptation" for slow-onset impacts or progressive climatic impacts. The interactions that occur between those who migrated and those who remained in the territories of origin, seeking to adjust their livelihoods to conditions of high climatic variability, cannot be captured when conceiving adaptation in such dichotomic terms.

\section{Literature Review}

The concept of "migration as adaptation" seems to have been firmly established in the sphere of international development aid agencies and global financers since the publication of the influential Foresight Report (2011), an extensive study by the UK government addressing the influence of global environmental change on migratory patterns in developing countries.

Since then, several international reports have taken up and strengthened this position (cf. FAO 2017; Rigaud et al. 2018). From this perspective, a narrative is constructed that emphasizes a positive view of migration as one of the most effective ways to diversify household income and contribute to a country's wealth, as well as to avoid climate threats, in particular, the increase in extreme weather events (rapid onset impacts). In addition, it is argued that preventing migration can lead to unsustainable outcomes and create a situation of trapped populations (Foresight 2011, p. 4).

The notion of migration as adaptation refers above all to the forced displacement of populations by extreme climatic and weather conditions. There is a substantial body of literature that qualifies these movements as climatic migration or environmentally induced migration (Gemenne and Blocher 2017; Piguet et al. 2011; Black et al. 2011; Tacoli 2009; Bardsley and Hugo 2010). Although with important conceptual and methodological nuances in the form and intensity of the role played by climate factors (conceptualized in the debate between maximalist and minimalist positions) and in the way of qualifying the population fleeing disasters (see Klepp 2017 for an in-depth review of the political implications of the terms used to categorize human mobility associated with climate change), these studies coincide in pointing out the multicausal nature of most migratory flows and emphasize the complex interaction between economic, social and political factors with environmental factors 
(Bardsley and Hugo 2010; Tacoli 2009, p. 107). Furthermore, Felgentreff and Plott (2016) indicate that it is not clear how to identify and separate environmental factors influencing migration empirically.

The common premise of this diverse literature is that migration is and will be a key response-conceived as an adaptation strategy - to the future impacts of climate change, whether they are rapid or slow-onset impacts. Therefore, it is argued that it is urgent to insert migration as an adaptive response in National Adaptation Plans (Sward and Codjoe 2012). Similarly, adaptation to climate change should be considered as part of migration policies, in order to regulate migration in an orderly and safe manner. In this sense, in December 2018, the intergovernmental Global Compact for Safe, Orderly and Regular Migration was agreed to by states globally, establishing the political basis at the international level to operationalize the migration and adaptation nexus, and raising the issue of climate change and migration on the international migration agenda (Newland 2019).

On the contrary, "adaptation in situ" refers to the idea that the practice of adaptation should take place in local environments so that people continue to live in their homeland and do not have to emigrate.

In situ adaptation is framed within the community-based approach to adaptation (c.f. McNamara and Buggy 2017 for an extended review of the concept) and ecosystem-based adaptation (c.f. Nalau and Becken 2018 for a review of the concept). Both lines share the common assumption of adaptation as a local scale intervention and in specific territories, although ecosystem-based adaptation extends its scope to biophysical scales such as watersheds or landscapes. This emphasis on the biophysical dimension and its connection to local livelihoods is the guiding principle of the in situ adaptation approach, although the question of how to scale up results is increasingly important. Therefore, the focus is primarily on environmental preservation, the introduction of sustainable agronomic practices and rural development planning. Most in situ adaptation is about defining adaptation strategies based on participatory management of environmental resilience and is carried out under the auspices of international agriculture and development organizations. The aim is to move towards greater environmental and climate resilience, which will eventually deter migration. In general, however, the analytical link with the migration issue is circumstantial. In Mesoamerica, and for the issue of coffee, a key cash-crop in the region, there is a considerable academic production which reflects the importance of in situ adaptation in this area of the world (c.f. Harvey et al. 2018; Chain-Guadarrama 2019; Imbach et al. 2017).

At the policy-realm, both approaches-on-site adaptation and migration as adaptation-are addressed in a decoupled manner. In the field of research, studies are also divided into one or the other line, as shown in the review by Upadhyay and Mohan (2014).

On this dichotomous view between in situ adaptation and migration as adaptation, Saleemul Huq, Director of the International Centre for Climate Change and Development (ICCCAD) and recognized expert in the field of adaptation, renamed this dichotomy as in situ adaptation versus planned relocation (or assisted migration), introducing an important nuance to the idea of denominating human mobility in catastrophic circumstances and in the face of climatic threats such as migration. Professor Huq questions the initial assumptions of the field of adaptation research as limited to the local scale, leaving aside the global and transboundary scale, advocating for a new paradigm of adaptation away from reactive responses to more proactive planning (Huq 2013).

\section{Critical Perspectives on Adaptation: From a Depolitized to a Re-Politized Adaptation View}

Scholars in the field of critical political ecology have criticized the idea of adaptation that prevails in the international policy arena on climate change and adaptation and in the literature linked to science and technology (c.f. Scoville-Simonds et al. 2019 for a recent review of the critical literature on adaptation). The fact that such a notion is rooted in the field of evolutionary biology (Taylor 2015) contributes to the neglect of social science analysis and the opinions and perspectives of local populations, often conceived as voiceless victims (Scoville-Simonds et al. 2019; Klepp 2017). 
Following their critiques, we can postulate that narratives engrained in the notions of in situ adaptation and migration as adaptation share a depoliticized view of adaptation in the sense that they obscure long-term dynamics in rural environments that give rise to strongly unequal socio-ecological relationships (Taylor 2015; Klepp and Chavez-Rodriguez 2018).

Issues such as the effect of agrarian transformation by liberalization of agricultural policies, uneven access to resources such as credit or the lack of distributive strategies of land and income (Taylor 2015); the role played by capitalist accumulation (Turhan and Armiero 2017); the dominant role of techno-science; and the asymmetries on which global markets are based, are all structural causes that remain excluded from the dominant narratives of adaptation (Taylor 2015, pp. 51, 61; Klepp and Chavez-Rodriguez 2018, p. 15).

This lack of attention to economic and climatic justice considerations (Klepp 2017) yields a reductionist narrative that evades tackling migration and its link with climate change as manifestations of a systemic crisis. In turn, the depiction of climate change as a purely biophysical phenomenon external to social reproduction generates the illusion of being something natural and apolitical. Such an image gives rise to a naturalized view of both adaptation and climate change in which social relations, power imbalances and the active coproduction between humans and meteorological forces remain obscured (Taylor 2015; Klepp 2017).

Regarding the migration-climate change nexus, scholars have also questioned the notion of migration as an adaptive strategy, based on similar criticism expressed for the idea of adaptation (Felli and Castree 2012). Another line of criticism points out that the discourse of "climate refugees" linked to "climate migration" implies a view of migrants as a threat to security but currently under the terminology of human security, resilience and adaptation (Bettini 2014). This discourse contributes to legitimating the neoliberal capitalist logic currently operating in the management of the migratory crisis (Felli 2013).

\section{Migration as Adaptation? A Depoliticized Narrative in the Context of the Mexican Southern Border Migratory Crisis}

The notion of migration as adaptation highlights certain positive aspects of the migration experience (Rigaud et al. 2018; Delavelle 2013; FAO 2017), while leaving out the current context in which border crossing takes place for a large majority of the world's migrant population.

The core narrative thread upon which the narrative of migration as adaptation is built is the idea of planning and advancing a safe, orderly and efficient migration. Another of its tenets is that migration is something that societies have undertaken throughout the existence of humanity in search of better living conditions. What is omitted from these narrative threads is an explicit reference to the increasingly restrictive and violent conditions in which migration currently takes place.

While noting that migration is a complex phenomenon and that environmental factors are difficult to isolate from economic, social or political factors, the notion of migration prevalent in reports, such as the World Bank's Groundswell (Rigaud et al. 2018), is greatly simplified. It operates on the illusion that current massive migratory movements can be controlled and managed in nonproblematic ways.

Underlying this flat notion of migration is the age-old fear of migration as a threat to national security and the invasion of hordes of migrants drawn as criminals and dispensable human beings (Hartmann 2010). This representation matches a long-standing discursive thread that inherited characteristic Malthusian stances and northern environmentalist discourses articulated around the fear of poor countries' populations (Bettini 2017, p. 11).

This narrative, although so conspicuous in the immigration politics exhibited by the Trump administration, is not exclusive to it. It also extends to those conflict borders of the Latin American world, such as the Venezuelan border (Valero Martínez 2016) and the Mexico-Guatemala border.

The southern border of Mexico has recently been subjected to new programs to control political borders (Ribando Seelke and Davis-Castro 2019; Torre Cantalapiedra and Quintero 2018; Castañeda 2016; Isacson et al. 2014). These programs were designed under the securitization doctrine (Varela 
Huerta 2015; Bigo 2002; Hernández-Gutiérrez and Sáenz 2018, p. 2), a term that refers to the militarization of social problems as a way to address them.

Neither the toughening of immigration control policies by the Trump administration (or that of his predecessor Barack Obama), nor his discourse of hate and criminalization against migrants, were able to dissuade thousands of Central Americans from fleeing poverty, widespread violence and a lack of opportunity in their home countries, in the so-called "Northern Triangle" that includes El Salvador, Guatemala and Honduras (ELCOLEF 2018).

\subsection{What Does This Situation Have to Do with the Coffee Rust Crisis in Central America?}

The humanitarian crisis on Mexico's southern border takes on media relevance when, starting in October 2018, several massive movements of Central American migrants-in groups of 2000 to 5000 people - crossed the Mexican borders towards the northern border with the United States (ELCOLEF 2018). A 70\% share of the members of the migrant caravans were of Honduran origin (ELCOLEF 2018). We have mentioned the importance of coffee for this country and its continued erosion since the impact of coffee leaf rust. It should also be noted that Honduras is a country with one of the highest vulnerability indexes ${ }^{1}$ due to climate change and that it is part of the Central American Dry Corridor, where most of its coffee production takes place and which is currently suffering from a long-term severe drought (Canet Brenes et al. 2016).

At the start of the crisis, the link between migration and climate change were hardly referenced in international media (Milman et al. 2018). From April 2019 onwards, reports and news relating to migrant caravans, the dry Central American corridor and rampant drought in recent years, water scarcity, and crop losses first appeared in the pages of international media (among many others see, for example: Gustin and Henninger 2019; Markham 2019; Blitzer 2019; Semple 2019). The role of the effects of climate change on coffee crops and its relationship with coffee leaf rust as a catalyst for migration in a context of poverty is thus linked to the phenomenon of Central American migrant caravans.

\subsection{Is a Safe and Orderly Migration Possible in the Current Context of Border Closures?}

As the increase in the transit of migrants in caravans increases, the situation on both Mexican borders worsens. Trump's threats to impose tariffs on Mexican exports to the U.S. have taken effect and the southern border has been militarized to prevent caravan transit. Thousands of people have been detained in temporary centers. We can refer here to a situation of trapped populations, but of a different nature to that alluded to in the literature of migration as adaption (Foresight 2011).

The approach of a safe and orderly migration is proposed against the backdrop of realities such as the one described above. We can question the possibility of articulating regional proposals based on the Global Compact for Migration. In this sense, few studies have analyzed the potential for coordination among states to establish migration policies that include the environmental component. For Neumann and Hilderink (2015), the possibility to partially operate the Global Compact for Migration is remote. For the European context, considered as a system of governance with experience in sectoral and interstate coordination, Geddes and Jordan (2012) conclude that the possibilities of designing policies that address migration, environmental change and adaptation to global environmental change in a combined manner are limited, partly due to the prevalence of the focus on securitization of current migration policies. For Latin America (Lejtreger 2019), results from evaluation of the integration of climate change and migration conclude that there is very little progress on the inclusion of migration in the proposals on climate change and adaptation.

1 Between 1993 and 2012, Honduras suffered more than any other country in the world from the scourge of extreme hydro meteorological events and is ranked first in the Germanwatch vulnerability index (CCAFS 2015: CGIAR Research Program on Climate Change, Agriculture and Food Security 2015. https://ccafs.cgiar.org/honduras (accessed on 23 October 2019). 
However, there are signs of the emergence of a counternarrative that addresses the migration-climate change-coffee nexus in Central America with novel approaches not included in the global reports. First, at the XXVI Ibero-American Government Summit (16 November 2018), in a brief speech, the president of Honduras addressed issues of climate justice, redistribution and regulation of the coffee trade chain-of which barely $1 \%$ of the benefits reaches the coffee grower-and the consideration of dignity and humanitarian treatment for those in transit to the United States, in a clear reference to the official violence against migrants (Presidencia 2018).

In parallel, two major reports have been published in 2019, raising the issue of human rights and migration, in conjunction with climate change, to the international policy arena. The first refers exclusively to the current coffee crisis. Elaborated by the Columbia University professor Jeffrey Sach, (Sach et al. 2019), it deals exclusively with the serious crisis of the coffee sector which, in 2019, experienced the lowest price level of the past 10 years. Sach proposes concrete measures to make effective a redistribution policy that guarantees a fair price to coffee growers, as well as the creation of a USD 10 billion fund to face the effects of climate change.

The second, from the Economic Commission for Latin America and the Caribbean (CEPAL 2019), prepares, along the same lines, an integral plan of development for Central America and Mexico with the suggestive title of "Towards a different style of development", with a narrative emphasizing the construction of a migration regime based on human rights and advocating for the development of migrants' places of origin and the generation of well-being by altering the patterns of inequity typical of the region. The plan received the joint signatures of the governments of the region.

The foundations for a new counternarrative are being set, based on the politics of wealth redistribution, the reformulation of the migratory framework, and with an integral adaptation proposal articulating economics, the environment and migration at all scales.

\section{Methods}

\subsection{Case Study}

The cultivation of coffee is of vital importance in Mesoamerica (Central America and Chiapas). The following data provided by the International Inter-American Institute for Cooperation on Agriculture (IICA by its Spanish acronym) (Canet Brenes et al. 2016) gives a snapshot of the importance of this cash-crop for the survival of the Central American rural population.

In Central America, coffee accounts for $20 \%$ of world exports and its cultivation occupies more than 1 million hectares. Small producers account for $80 \%$ of coffee growers. Coffee generates 1.8 million jobs. Of all the countries of the Central American isthmus, Honduras stands out as the third largest producer of Arabica coffee in the world, with $70 \%$ of its rural population below the poverty line (Canet Brenes et al. 2016). On average, the pest has affected more than $50 \%$ of the total coffee producing area of Central America and production for the 2012/2013 harvest was reduced by approximately 20\%. According to the World Forum Program (WFP), the impact of coffee leaf rust has led to a situation of food insecurity for more than 157,000 families in Honduras, Guatemala and El Salvador, mainly small producers and day laborers (Canet Brenes et al. 2016).

Chiapas, located at the southern border of Mexico with Guatemala, is the first coffee producer in Mexico. In 2018, it contributed 41\% of the total coffee produced in Mexico (INCAFECH 2019). It is also the first state producing organic coffee $(73 \%)$ in the country, whereas Mexico is the world's second largest producer of organic coffee (SIAP 2015). In Chiapas, approximately 180,000 families live on coffee-related income, of which $61 \%$ are indigenous. Chiapas is also the state with the largest cultivated area of coffee in the country (35\%, 252,744 ha) (INCAFECH 2019).

One of the most emblematic coffee-growing areas is the cross-border territory of the Tacaná Volcano, at the southwestern end of the border strip of the Soconusco region. Three municipalities-Unión Juárez, Tapachula and Cacahoatán-administratively make up this volcanic massif at an altitude of $4000 \mathrm{~m}$ above sea level. Over its summit passes the border line that divides Chiapas and Guatemala. 
At the end of the 19th century, the production of coffee began in this area (Figure 1) in a context of colonization. To this day, coffee is still the main crop in the area, now on community-owned land. Small producers grow Arabica coffee under shade at altitudes between 1000 and $1700 \mathrm{~m}$ above sea level in agroforestry plots of an average of 2.5 ha. Robusta coffee-the other commercial coffee species used in soluble coffees-dominates at low altitudes between 600 and $1100 \mathrm{~m}$. In 2001, a conservation zone was established that includes the volcanic crater and the high slopes, the Tacaná Volcano Biosphere Reserve. In the buffer zone, coffee production established prior to the conservation decree is permitted; however, the establishment of new production plots is not.

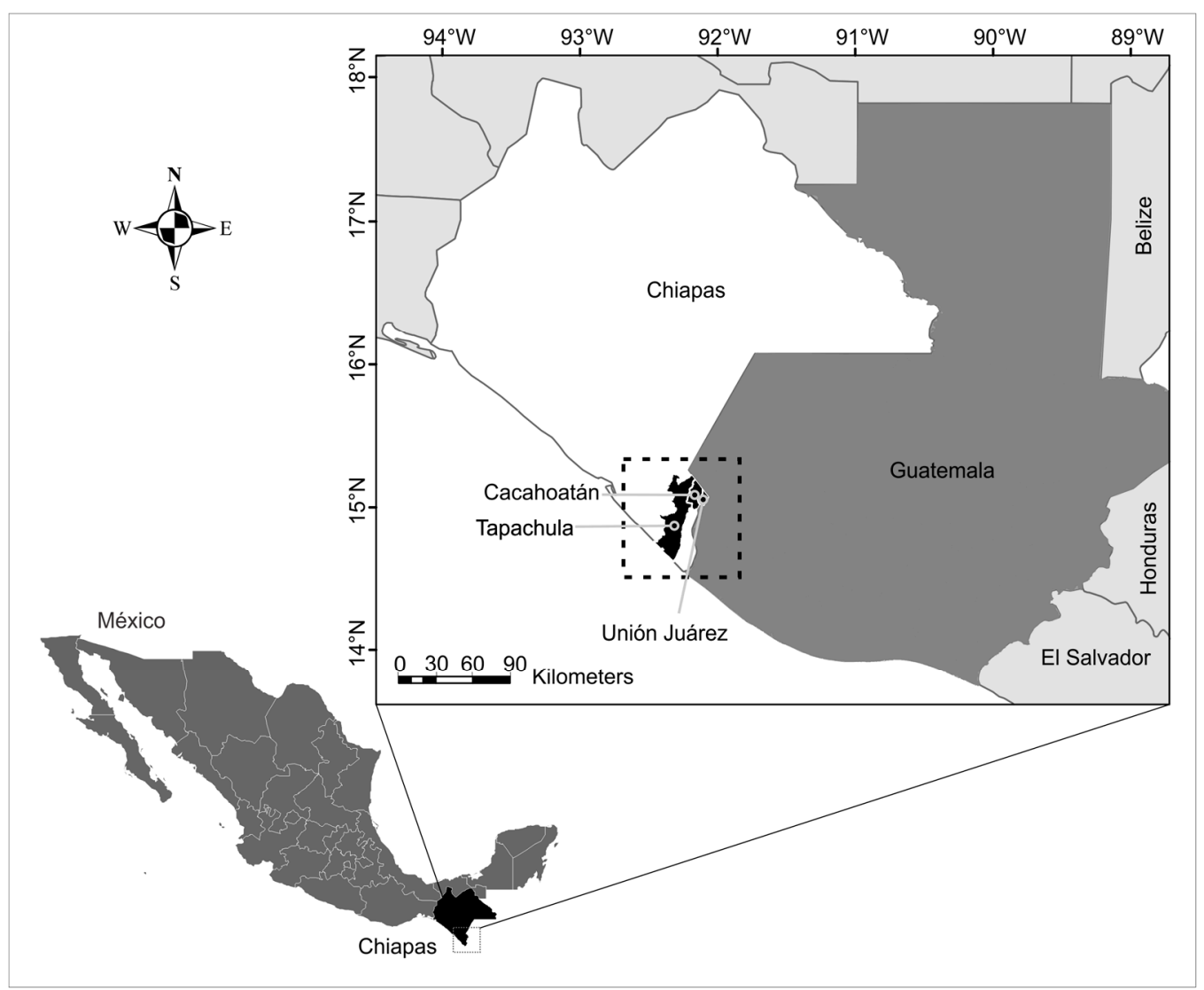

Figure 1. Map of the locations of the three municipalities of study along the Mexico-Guatemala border in the Soconusco region. Tapachula is the second most populated municipality of Chiapas. The three municipalities are part of the highlands of the Tacaná Volcano, but only Unión Juárez (at 1200 m.a.s.l.) lies entirely within the buffer area of the Biosphere Reserve of the Tacaná Volcano. Prepared by Yair Merlín-Uribe.

Coffee production, both in the past and in the recent history of the area, has triggered migratory flows of diverse nature. The intensity and frequency of these migratory flows have varied throughout the last century, depending on fluctuations of international coffee prices and of the Mexican and Guatemalan national agricultural and migratory policies. Today, to these are added the current climatic variability, such as the alteration of rainfall and temperature regimes, commonly associated with climate change (Hannah et al. 2017; Imbach et al. 2017; Gay et al. 2006). Experts on climate change modelling agree that these alterations widen the range of action of pathogens that attack crops (Avelino et al. 2015).

This seems to be the case of the last epidemic of coffee leaf rust, a disease produced by the fungus Hemileia vastatrix, during 2010-2013 in the whole area of Mesoamerica, as well as in Colombia and Peru (McCook and Vandermeer 2015). The fungus was present at higher altitudes, previously free of this disease, and its unusual appearance seems to be associated with the effects of climate change. The 
link between climate change and coffee leaf rust has been deduced indirectly from climate scenarios that forecast conditions that would favor the propagation of illnesses and plagues (Bebber et al. 2016). Avelino et al. (2015), clearly establish that the spread of leaf rust cannot be fully attributed to climate variability. Other factors, the effects of which are aggravated by climate change, include the difficulty of replacing old coffee plants; limited management given the lack of income; market shocks; and, in particular, according to Renard and Torres (2017), the long-term negligence of the state in drafting policies that protect coffee cultivation.

\subsection{Analytical Strategy, Data Sources and Collection}

Following a case study approach, the article adopts a narrative analysis to the research of the migration-adaptation-coffee nexus. We follow the concept of narrative proposed by Bell (2013), understood as the way humans organize experience by formulating stories at collective or individual level, with which an argumentation over a particular topic is constructed, that entails the production of shared understandings and interpretations of social life (Bell 2013).

The analytical strategy is based on the proposal of the thematic narrative analysis "that mainly examines what content communicates a narrative, rather than how a narrative is constructed" (Riessman 2008, p. 73), and has been used to understand the production of meaning (Felgentreff and Plott 2016).

The analysis is divided into two distinct lines: the first adopts a regional scale of observation to develop the discussion on migration as adaptation. We analyze the main narrative threads-or arguments that are repeated through the different policy documents of international organizations.

The second strategy focuses in our case study and adopts a local scale of observation at municipal and community level to address in situ adaptation from the coffee leaf rust epidemic case.

We first present a statistical description (Section 4), to show basic trends of the migration dynamics in Chiapas and in our three municipalities of study (Figure 1), where coffee is a key economic activity. This was done to provide a quantitative view of the magnitude of the migration phenomenon in the area of study. We selected a time series from 2003, just after the onset of the international coffee crisis, until 2015, to include the peak, in 2013, of the coffee leaf rust outbreak.

We attempted to identify the signs of migration associated with coffee leaf rust and describe demographic variations before and after this year with the data available. Different national data sets were consulted (see Table 1): sources 1 and 2, for demographic variability at state and municipal level; source 3, for migratory dynamics; and source 4 to analyze coffee producing trends at state and municipal level.

At community level, and adopting an ethnographic approach, we conducted a qualitative analysis to represent the subjectivity of coffee growers and their experience in addressing the renovation of their coffee plantations in a context of climate change. We focus on three transboundary communities of the Tacaná Volcano that are adjacent to the buffer zone of the Biosphere Reserve (Section 5).

The narrative data around the in situ adaptation strategy are constructed from extensive conversations-mostly recorded-of personal stories of the coffee growers who live in this transboundary region between Guatemala and Chiapas. We conducted in-depth interviews with coffee growers on the Mexican side of the border in the communities of Talquián (1700 m.a.s.1., 27 interviews), Unión Juárez (1200 m.a.s.l., 12 interviews) and Santo Domingo (1000 m.a.s.1., 8 interviews), in the Municipality of Unión Juárez (Section 5). Most of the interviews took place in the coffee plots. Leaders of Mexican farmers' organizations, technical government personnel in the field, and experts and agronomists from non-governmental organizations and regional companies involved in the reproduction of new hybrid varieties of coffee were also interviewed. This allows a triangulation of sources between the experience of the coffee grower and the more institutionalized narratives. The fieldwork took place between October 2017 and June 2019 (Figure 1), in periods of approximately one week per month and as part of a wider project. 
Table 1. Data used to cover analysis in Section 4. A variety of data sources have been used to compensate for gaps in information. Elaborated by Yair Merlín.

\begin{tabular}{|c|c|c|c|c|}
\hline Item & Data Source & Temporal & Spatial Coverage & Measure Used \\
\hline $\begin{array}{l}\text { 1. National } \\
\text { Population } \\
\text { Censuses }\end{array}$ & $\begin{array}{l}\text { National Institute of } \\
\text { Statistics, Geography } \\
\text { and Informatics } \\
\text { (INEGI). Federal } \\
\text { government. }\end{array}$ & $\begin{array}{l}1990,1995, \\
2000,2010\end{array}$ & $\begin{array}{c}\text { Chiapas } \\
\text { municipalities }\end{array}$ & $\begin{array}{l}\text { Count of the } \\
\text { resident population } \\
\text { and distribution by } \\
\text { municipality }\end{array}$ \\
\hline $\begin{array}{l}\text { 2. Intercensal } \\
\text { survey }\end{array}$ & $\begin{array}{l}\text { National Institute of } \\
\text { Statistics, Geography } \\
\text { and Informatics } \\
\text { (INEGI) }\end{array}$ & 2015 & $\begin{array}{c}\text { Chiapas } \\
\text { municipalities }\end{array}$ & $\begin{array}{l}\text { Count of the } \\
\text { resident population } \\
\text { and distribution by } \\
\text { municipality }\end{array}$ \\
\hline $\begin{array}{l}\text { 3. Survey of } \\
\text { Migration at } \\
\text { Mexico's Southern } \\
\text { and Northern } \\
\text { Border }\end{array}$ & $\begin{array}{l}\text { Northern Frontier } \\
\text { College (COLEF). } \\
\text { Public research } \\
\text { center. }\end{array}$ & 2009-2016 & $\begin{array}{l}\text { Southern and } \\
\text { Northern Border } \\
\text { of México }\end{array}$ & $\begin{array}{l}\text { Count of flows } \\
\text { coming to Mexico } \\
\text { in southern border } \\
\text { and count of flows } \\
\text { going to United } \\
\text { States in the } \\
\text { northern border* }\end{array}$ \\
\hline $\begin{array}{l}\text { 4. Annual Coffee } \\
\text { production report } \\
\text { of Chiapas } \\
\text { municipalities }\end{array}$ & $\begin{array}{c}\text { Agrifood and } \\
\text { Fisheries Information } \\
\text { Service (SIAP); } \\
\text { Ministry of } \\
\text { Agriculture and } \\
\text { Rural Development. } \\
\text { Federal government. }\end{array}$ & 1995-2016 & $\begin{array}{c}\text { Chiapas } \\
\text { municipalities }\end{array}$ & $\begin{array}{c}\text { Production, yield } \\
\text { and prices of coffee } \\
\text { by municipalities } \\
\text { of Chiapas }\end{array}$ \\
\hline
\end{tabular}

\footnotetext{
${ }^{*}$ It refers to the number of migrants entering and leaving (the inflows and outflows) of a country during a specific period of time and space.
}

The interviews were analyzed using Atlas-ti software (Scientific Software Development GmbH 2018), following a qualitative strategy of coding in several stages (Creswell 2013). Due to the focus on narratives, we moved away from the classic microanalysis of word-by-word coding (Glaser and Strauss 1967). Instead, we privileged the paragraph as the basic unit of analysis to preserve the narrative structure and construction of meaning in the argument provided (Riessman 2008). First, a predefined set of topics of interest was used to classify the interview material. Second, emerging socio-ecological processes associated with these issues were then identified. In a third phase, migration issues were crossed with those of coffee production in a matrix of meaning.

The initial thematic classification was on the experience of coffee growers with new coffee varieties-problems encountered, preferences and traditional varieties versus new hybrid varieties; knowledge of coffee leaf rust and its relationship with climate change; participation in Procafé's federal program and its deficiencies; participation in private renewal programs carried out by international companies or international foundations; perceptions of climate change and how coffee farmers have been dealing with it; and the future of coffee activity in the region and personal views on how to address the coffee leaf rust crisis.

The theme of migration was codified into the following topics, not previously predefined: current and past migration patterns; international migration and internal migration and their relationship to in situ adaptation measures for coffee renovation; the influence of living in a cross-border region for coffee production; and the experience of being deported. Finally, issues related to coffee production and issues related to migration experiences were combined in a matrix and new codes were assigned. 


\section{Migration, Coffee and the Market in Chiapas and the Tacaná Volcano: Dimensions, Interactions and Effects}

Migration in Chiapas has been a historical reality. At present, flows of out-migration, immigration and transit migration converge and overlap in this territory. Among the easily identifiable migratory flows of the Soconusco cross-border region, we find asylum-seekers and economic migrants from Central America-and, during the first semester of 2019, Cuban, Haitian and Central African migrants; workers that daily cross to the Mexican border city of Tapachula, the largest urban center of the zone; Guatemalan and Mexican workers in agro-industrial banana or palm oil plantations on the region's coastal plains; the historic flow of Guatemalan migrant farm workers to large private coffee plantations in the Soconusco region during the coffee harvest (Figure 2); and the out-migration of residents of Chiapas toward the states of northern Mexico to work in agro-industrial plantations, or try to cross illegally into the United States (Villafuerte and del Carmen Aguilar 2006).

Despite this complexity, Chiapas' current migration profile resembles major global trends, particularly those highlighted in a recent World Bank report (Rigaud et al. 2018), pointing to the growing importance of internal migration around the world. For its part, the Economic Commission for Latin America and the Caribbean (CEPAL 2018) and other Latin American regional organizations emphasize the importance of transboundary migration in this region. Both tendencies are prominent in the migratory dynamics of Chiapas (see Figure 2).

On the one hand, international out-migration to the United States dropped sharply since the 2007 crisis and continues to decline: from 2010 to 2016, this flow decreased by up to 80\% (COLEF 2016b). On the other hand, internal migration to the northern states of the country has increased: since 2014, national emigration has remained slightly greater than international out-migration (COLEF 2016b) (see Figure 3).

Finally, return immigration to the state of Chiapas is reaching levels similar to the current level of out-migration: by the year 2016 the gap between emigrants going to the United States and those who returned from it approached the same level, with a slight upward trend of the in-migration flow towards the south (Figure 3) (COLEF 2016a). In spite of this, Chiapas still maintains a negative migratory balance: emigration exceeds immigration by $25 \%$ (INEGI 2015).

In this context of reduced international out-migration and increased return flows, cross-border migratory movements have intensified (see Figure 2).

Migratory crossings in the municipalities of Tacaná Volcano, on Mexico's southern border: places of origin and destination and percentages of crossings:

This migratory dynamic makes Chiapas a state with slow population growth with average annual rates below $2.3 \%$ since the 1990s. Our area of study follows this same dynamic, which is even accentuated in the case of Unión Juárez, whose population decreased during 1990-1995 and 2000-2005 below the average state rate (Figure 4). No newer data are available regarding the number of people who departed from the municipalities that we studied. The most recent data are for 2009-2014, and they are aggregated at the state level in the 2014 National Demographic Dynamics Survey (INEGI 2014). 


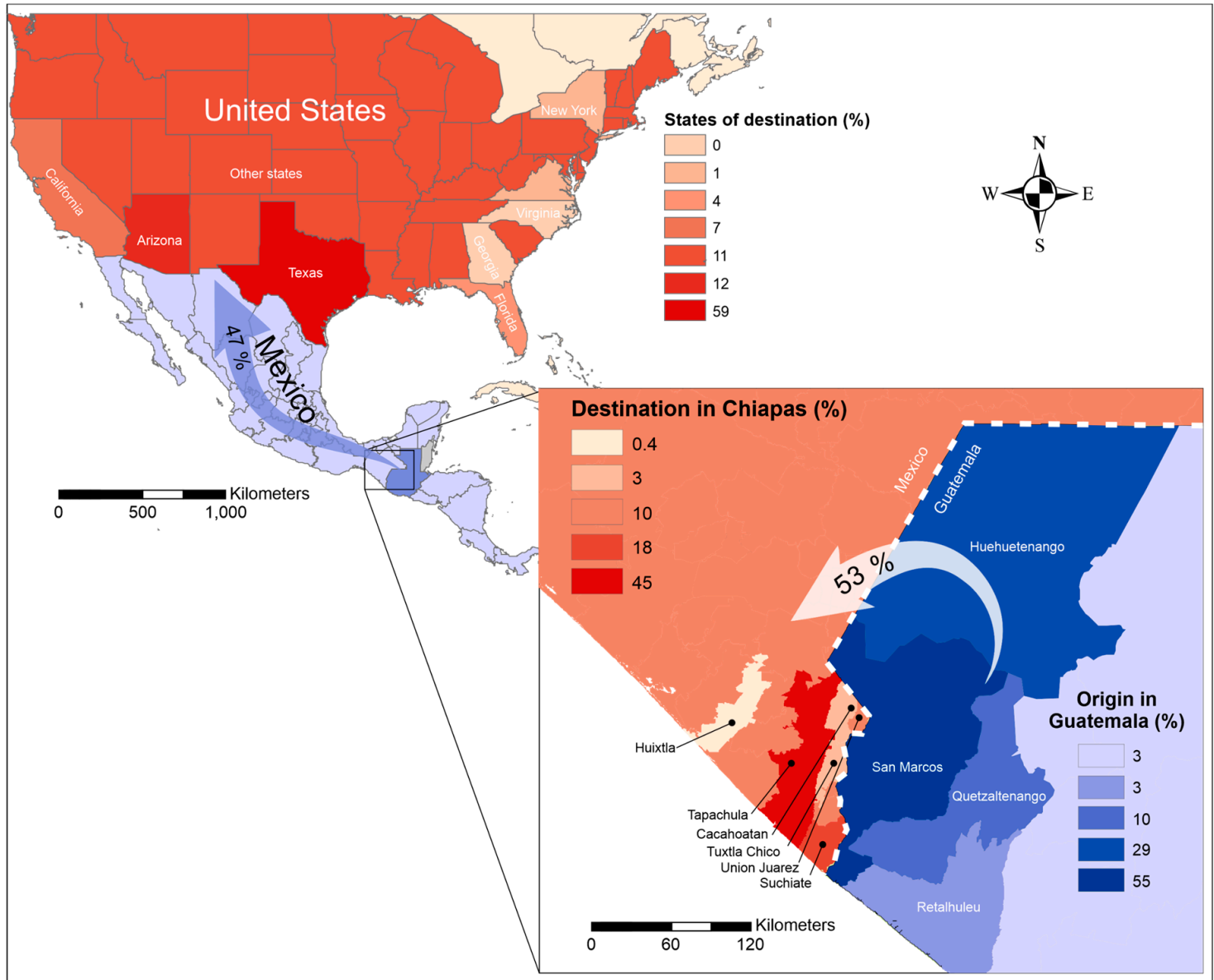

Figure 2. International and transborder migratory flows of the Guatemalan population on the Chiapas-Guatemala border, differentiating percentages of cross-border migration to the main municipalities of Chiapas and the flow of Guatemalan migrants to the United States (transit migration), with Texas and Arizona being the main destinations of this trans-migrant population. Sources: (COLEF 2016a, 2016b). Prepared by Yair Merlín-Uribe.

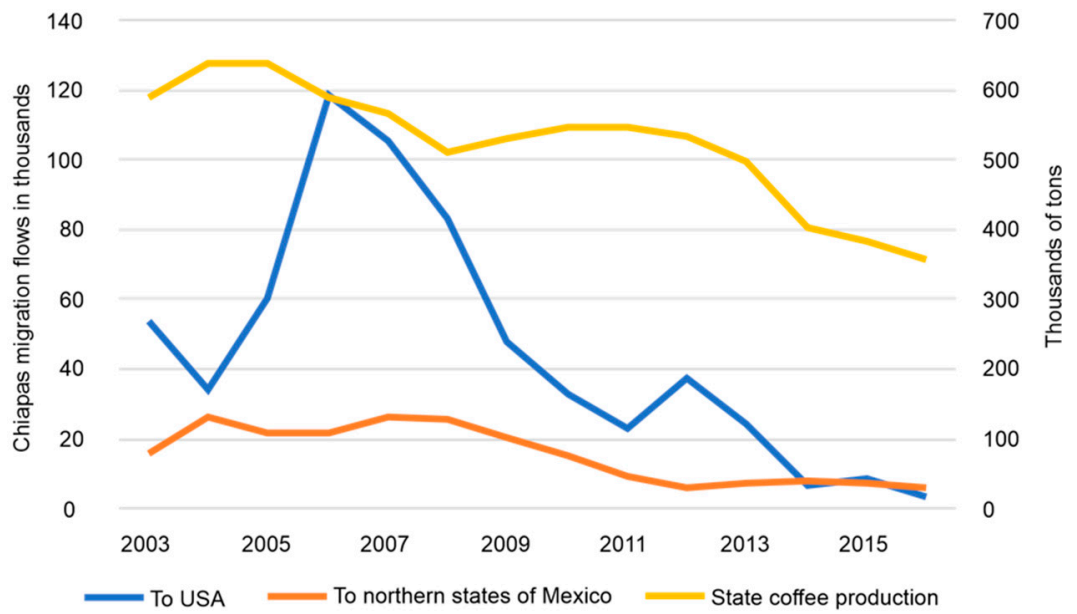

Figure 3. Dynamics of migratory flow and coffee production in Chiapas. Since 2012, lower production has coincided with declining out-migration to the north of the country or the U.S. Source: (COLEF 2016b) and (SIAP 2015). Prepared by Yair Merlín-Uribe. 


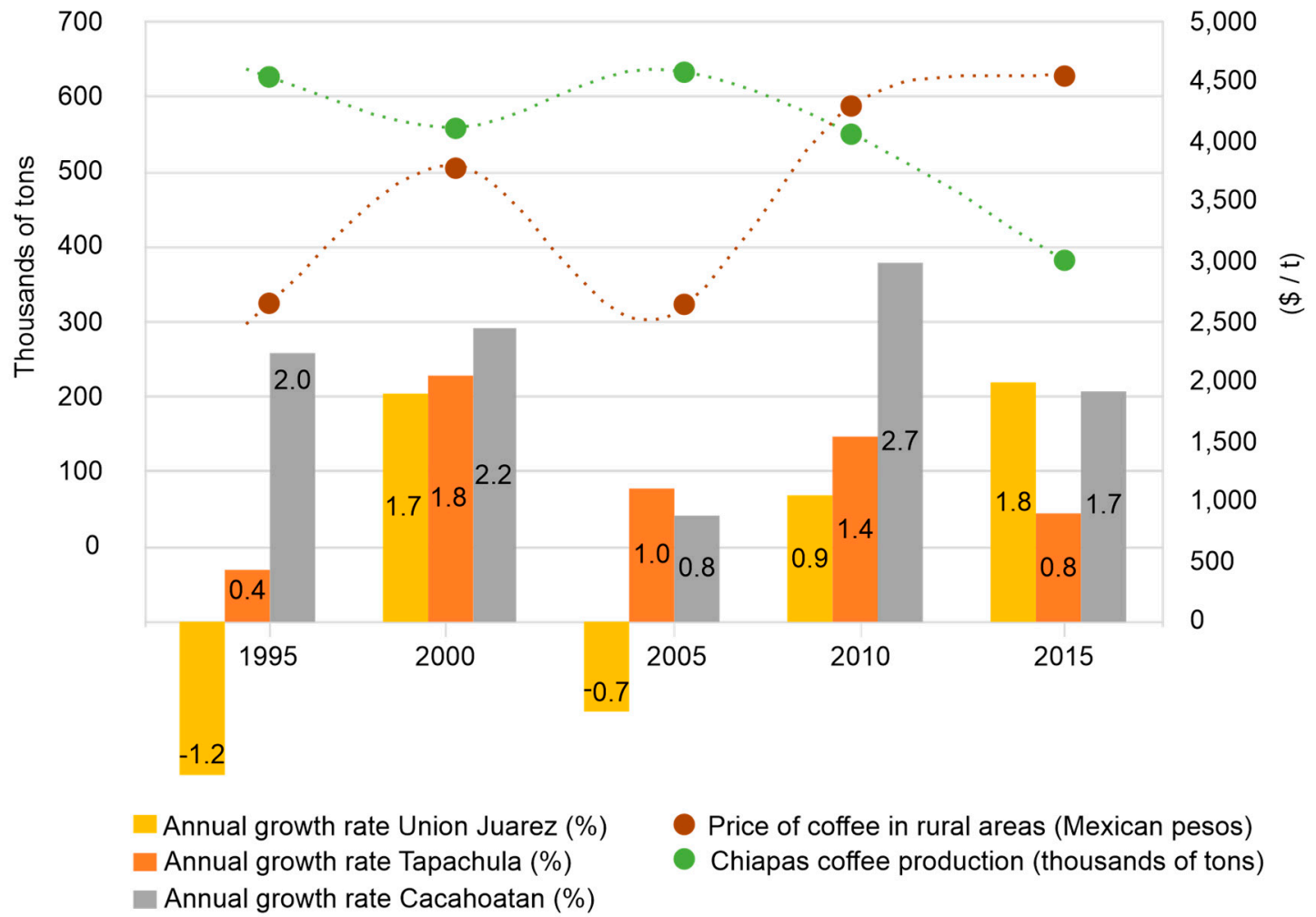

Figure 4. Population growth in the municipalities of Tacaná Volcano and Chiapas coffee production and prices. Depiction of how the price and productivity of coffee affects the population dynamics of the municipalities of interest. Annual increases and decreases in average population growth follow the ups and downs of coffee prices. In addition, coffee production and price are inversely related. Source: INEGI, 2015 and SIAP, 2015. Prepared by Yair Merlín.

4.1. How Does Coffee Leaf Rust Interfere with Current Migratory Flows? Coffee Productivity, Prices and Migration in Chiapas and in the Municipalities of the Tacaná Volcano

In order to answer this question, we contrast the demographic alterations that occurred between 2003 and 2018 in the state of Chiapas and in the municipalities under study, with the variables of coffee production and price in the same period, to identify joint or disparate patterns.

International migration peaked in 2007, after recovering from the international coffee crisis in 2002, when it had one of its lowest levels. From 2007 onwards, a period of abrupt decline began and continues to this day, as stated above (Figure 3).

In relation to coffee productivity, a downward trend associated with the liberalization of the international coffee market and the end of the sponsored coffee cultivation by the Mexican government began in 2005 and has continued steadily to this day (Renard and Breña 2010).

Between 2003 and 2016, coffee production decreased constantly (Figure 3). At the state level, the decrease was $42 \%$. However, losses in coffee production in the municipalities we studied exceeded the state average by far: 74\% in Cacahoatán, 69\% in Tapachula and 81\% in Unión Juarez (the municipality most affected). Yields follow the same downward trend: the state-level loss was 31\%, but losses in our study locations dropped by more than double that amount (64\%-68\%, FIRA 2016).

During 2013-2014, production losses accelerated as a result of coffee leaf rust (Figure 3), whereas out-migration to the US decreased sharply during that same period-precisely at the peak of the disease. It is notable that both the 2014 migratory crisis at Mexico's U.S. border and the ensuing enforcement of migration controls at its Guatemala border ultimately coincided with the attack of coffee leaf rust in our location of study. 


\subsection{Low Prices as a Push Factor for Migration? Migration, Low Coffee Prices and Declining Productivity}

The comparison of the trends in coffee productivity with price behavior (Figure 4) offer some insights to understand relationships between production decline and market behavior and its effect on migration in the municipalities of Tacaná Volcano.

The post-2010 decrease in production occurred while coffee prices increased, a tendency that continued and became more marked during the coffee leaf rust outbreak. The peak of coffee leaf rust in our study area took place in 2013. In that year, the price of coffee reached its peak, while the decline in harvests accelerated (Figure 4). Following the signals of supply and market demand, the production level and purchase price of coffee seem to show the opposite behavior: the higher the production, the lower the purchase price.

From a long-term perspective, the price paid to producers for a ton of coffee in rural areas trended upward from 2005 to 2015 (Figure 3) ${ }^{2}$. At the state level, the increase was 130\%. However, it was significantly lower in the three studied municipalities: $11.4 \%$ in Cacahoatán, 19.9\% in Tapachula and only $9.9 \%$ in Unión Juarez (SIAP 2015).

Data also show that when production is high, and prices fall, there is a downward trend in population-possibly an effect of migration (Figure 4). For the period 2010-2015, moderate population growth in these municipalities is observed when the price peaks, despite the downward trend in harvests.

The data shows a coupled relationship between the price of coffee and the size of the population. Low prices unleash migratory flows that lead to a reduction in population. Considering that tendency and considering that coffee leaf rust implies losses in production, the epidemic itself would not affect the migratory process directly, but the low prices of coffee would (Figure 3).

Two more factors could be interfering with the decision to migrate in the face of declining harvests, in addition to low prices. One is that the positive effect of prices on restraining migration can be downplayed if inflation rates are taken into account. In this sense, the high rate of inflation of $83.6 \%$ during the same period (INEGI 2019) prevented an increase in household income from the sale of coffee, despite the moderate rise in coffee prices.

The other refers to the spatial insertion of the study municipalities on the transborder space of the Chiapas-Guatemala border, adjacent to the hot spot of the migratory crisis on the southern border of Mexico. Despite the loss of coffee productivity, the new anti-migration policies in the United States could have exerted a deterrent effect on the intention to migrate, while interfering with coffee production and commercialization.

The importance of having prices above the poverty line for coffee to prevent migration should prompt rethinking of the wisdom of following a coffee renovation strategy that promotes quantity of yields over quality, as we shall show in the next section. If market prices for coffee are not giving returns that exceed the necessary investments, perhaps it is time to consider alternatives that produce moderate yields of high-quality coffee that fetch higher prices.

Current neo-liberalization policies exemplified by a highly inequitable market in the distribution of benefits are downplaying coffee benefits to the coffee farmers, while allowing for substantial profit margins to international roasters and retailers (Renard and Torres 2017; Merlín-Uribe et al. 2018). Far from promoting sustainable means of living (Merlín-Uribe et al. 2018), they are driving current waves of migration. The following testimony crudely reflects the inequality of the effects of the coffee leaf rust epidemic on those involved in coffee cultivation: "You know who was the hardest hit by the coffee leaf rust? Only the poor." (JM, 61 years. Córdoba Matasanos, Unión Juárez, 29 January 2019).

2 This was associated with the long drought that affected production in Brazil, whose green grain harvest dictates the price level. This is because Brazil is the world's largest coffee producer and exporter (Canet Brenes et al. 2016). 


\section{In Situ Adaptation: Ethnographic Notes on Migration, Coffee Leaf-Rust and Climate Change from the Tacaná Volcano Borderland Region}

The changes introduced in the wake of the coffee leaf rust outbreak can be viewed as a strategy for adaptation in situ, which, if it achieved the desired success, would help reduce future emigration. However, these adaptive changes are marked by paradoxes and contradictions, some of which interfere in different ways with migratory flows, whether international, internal or cross-border.

Paradoxically, this migration is helping to finance coffee plantation renovation efforts that would fall under the category of "adaptation in situ". Might we, then, speak of an in situ adaptation financed by migration as adaptation? Before addressing this issue, we present a brief overview of how in situ adaptation is taking place in the coffee plantations in our study area.

\subsection{Chaotic In Situ Adaptation: Coffee Leaf Rust, Institutional Mismatches and Unknown Seeds}

The replacement of locally-adapted varieties of Arabica coffee-primarily Typica and Bourbon, which are highly susceptible to coffee leaf rust-with hybrid varieties like those derived from the hybrid of Timor (Arabica-Robusta crosses, in principle resistant to coffee leaf rust), became the focus of the renovation efforts to improve productivity after the coffee leaf rust infestations.

This substitution process was led, among others, by a government program called Procafé, which organized the production and distribution of hybrid coffee seeds and plants through peasant organizations and private farms. However, in our area of study, the substitution process was rife with inefficiency, lack of information and uncertainty about the quality of the plant material delivered, together with patronage practices that detracted from the efficacy of the renovation process and heightened the risks of coffee production in the ejido (communal-owned land) sector.

“( . . ) In the beginning, the government entrusted the large coffee farms with the production of coffee plants. Yes, they made billions of plants and paid them well ( . . ), MEX \$ 4 for the plant, and to produce a plant in that time, it cost MEX $\$ 1$ with 28 cents ... It was a good business. Then the peasant organizations, like mine, began to fight (... ), and they became producers of plants. Now they are being paid MEX $\$ 6$ a plant, and the cost of production is MEX \$1.98. Some peasant leaders have become millionaires by producing and selling coffee plants with government seeds". (HG. 65, leader of the Democratic Peasant Union and Commissariat of the community of Santo Domingo, municipality of Unión Juárez, 19 November 2018).

In the course of our field work, we identified problems such as poor quality of the plants delivered, which were sometimes already afflicted with other sicknesses and confusing information about the variety delivered and its management requirements. All this generated mistrust among the producers about the quality of the seed delivered and the process of plant production in nurseries, as one of the youngest coffee growers we talked to told us.

"How is it possible that the coffee plants came already infected from a nursery? I mean, they delivered plants of bad quality ... I don't think they were a 100\% selected seeds, treated seeds ... Last year, from the community of Trinidad, they brought in plants, and they had already coffee leaf rust!". (GM, 43, coffee grower, Unión Juárez community, 16 November 2018).

Other situations recounted by coffee farmers were the need to apply agrochemicals in a context of organic production; yields with initially high productivity but lower bean weight; difficulties in maintaining coffee leaf rust resistance in successive generations of recently introduced cultivars due to the speed at which the fungus mutates; delivery of fewer seedlings than promised by the program; and the lack of sustained technical assistance.

On some occasions, the same service providers contracted by PROCAFE federal program refused to use the seeds handed in to produce coffee plants and distribute them to coffee farmers. 
"Look, (the informant breaks a sack of seeds, grabs a handful and throws them to the ground), this seed is useless. I told my boss, "I won't plant that seed again because it creates problems for me with the people, because that seed doesn't work". And with my boss, we went to buy catimore seed here, on the other side, in Guatemala". (DJ., 62, worker in PROCAFE service provider nursery, Unión Juárez, 17 November 2018).

Similar situations were encountered in other regions of the country and in other municipalities of Chiapas regarding the renovation of coffee plots and the distribution of seeds under the government federal program (Renard and Torres 2017; Henderson 2017).

For our area of study, producers show a clear preference for traditional varieties of high cup quality, but of low productivity and high sensitivity to rust. In the dilemma between productivity and cup quality, PROCAFE's policy seems to bet on the former to the detriment of the latter, delivering hybrid seeds of high productivity but with inferior qualities to traditional varieties, such as Costa Rica 95.

However, international organizations, such as the World Coffee Research Institute, are embarking on a crusade to design varieties of high resistance, good cup quality, high productivity and resilience to climate variability (Toniutti n.d.; World Coffee Research n.d.). From this research, a new generation of hybrid varieties is being released to the market (for example, Millennium or Casiopea produced in genetic laboratories in Costa Rica) (field-work, Laboratory of Genetics, CATIE, Turrialba, Costa Rica, 3 October 2019). These seeds are not yet available in Mexico for the small producer, but according to the experts who produce them, their improved genetic characteristics will be crucial to cope with periods of prolonged drought and the greater intensity of rainfall predicted by climate models. At the moment, they are only accessible to large producing farms with the financial capacity to acquire them (DJ, 5 October 2019, Seed Bank of the Tropical Agricultural Research and Higher Education Center, CATIE, Turrialba, Costa Rica).

The search for the "magic" variety (productive, of good quality, resistant to rust and accessible price) has generated a web of narratives on both sides of the border. Acquiring seeds of resistant varieties and producing them informally and without certification on the Guatemalan side of the border is becoming an option for coffee growers on the Mexican side, whose experience with government-delivered seeds was unsuccessful. No one knows with certainty which is which in this transfer of seeds and coffee plants. However, informal experimentation, word of mouth and mistrust of "official" seeds form an alternative innovation landscape independent of seed laboratories, with uncertain but very dynamic results.

All this chaotic exchange of seeds, knowledge, new varieties, subsidies and uncertainties around a process of change never before seen at this magnitude rests on institutional weakness and the need for short-term results from producers. In addition, it jeopardizes a much-needed adaptation strategy that will need to be constant in the face of increased climate variability in the medium term.

\subsection{Weather Changes and Coffee Rust: Who's to Blame? Us or the Government?}

Unusual climatic variability is already being felt by coffee farmers. Erratic rainfall, later flowering of coffee plants, and the intensification of rains and their reduced but more destructive duration are commonly mentioned as the impacts of altered weather patterns by coffee growers in the highest-altitude communities in our research project (Talquián, 1700 m.a.s.l. and Unión Juárez, 1200 m.a.s.l., field diary, 2018).

Calendars of sowing, harvesting and pruning coffee trees are trying to be adjusted to match new periods of rain or changing temperature patterns. An incipient narrative linked with the changing weather patterns has a constant presence in the area. However, uncertainty dominates over which course of action to take, as indicated:

"Before everything had a date, because people, well, our parents, ( . . ) knew "we are going to sow corn now in February, March, because the rains are coming". Right now there is no 
order ( ... ). We can no longer trust the weather. We no longer know what day it rains, nor what day it does not rain". (BR, coffee farmer, 32, Talquián Viejo, October 2018).

Rarely is this instability associated with climate change. The tendency of many of the rural inhabitants of the area is to take responsibility for not having taken care of nature. The belief that their rubbish and logging effected by themselves are the main reasons for climate change is a prevalent feature of this narrative.

When questioned about coffee leaf rust's origin, few coffee farmers connect the phenomenon of climate change with the increase in pests and illnesses. An overwhelming majority of coffee farmers share a narrative that puts the blame for the presence of coffee leaf rust on the ongoing local fumigations that the international program MOSCAMED - a coordinated effort to eradicate the Mediterranean fruit fly, a devastating pest globally_implemented since 1985 (Méndez Espinoza et al. 2006): “Well, right now in these times, everything has changed a lot, with all the technology. We did not know the coffee leaf rust. We began to see it, when those planes began to enter to throw a fly; a mosquito they threw away; it brought an orange powder ... ". (JL, 63, Talquián, 11 November 2018).

Such a belief builds a narrative that expands across both sides of the border with a solid conviction: that coffee leaf rust is sprayed from MOSCAMED's light aircraft following government instructions, "to finish us off", "to destroy our way of life" or "to force us to buy new coffee plants, and make business through it with the big companies" (H. coffee farmer and campesino union leader, 62 years old, Santo Domingo, Unión Juárez Municipality, May 2018 and June 2019).

Regardless, the understanding of what climate change is and the connection with coffee leaf rust is hardly mentioned. Deforestation and pollution of rivers and lands because of the dumping of rubbish are considered the main causes of climate change. The general tendency among respondents is to blame themselves for such a state. Those statements are followed by warnings about the destruction of nature and the punishment humans will suffer because of this:

"God says that times are going to change and yes, well, times are changing, tremors are coming; the rains pass stronger, like the rain right now hits but as if it was mad at you. And yes, then I say, if everyone read the Bible, all this will change; the climates would also return to normal, the tremors would no longer happen, and God would be happy with us now". (B. woman coffee farmer, 32 years old. Community of Talquián Viejo, Municipality of Unión Juárez, Chiapas, 26 October 2017).

\subsection{Migration, Coffee and Next Generations: What Is There for Young Coffee Growers?}

Coffee growers are aware of the uncertainty associated with generational turnover. When asked about the issue of succession, they often remain silent, or say they worry about not knowing what will happen to their land.

The coffee plantations are abandoned because many people have already left for the United States (...). I have many friends who are from here and are in the United States; that is because the lands no longer interest them; there, they dedicated themselves to building or to work in factories; ( ... "Why am going to get back to coffee, if it is not going to produce enough for me to live?". That is what they think. We are very few who are interested in coffee production. (MZ. 45. Coffee farmer, Santo Domingo, 28 March 2019).

Today, migration has a different face from the migratory wave that was initiated at the end of the 1990s (Villafuerte and del Carmen Aguilar 2006) as a result of the international coffee crisis: that of the new descending generations of older coffee growers who still work on their plots. Faced with the difficulties of finding a first job in the city, the option of migrating becomes attractive.

On the other hand, young coffee growers that opt to remain in their homeland are taking advantage of digital technologies using social networks and video information through cellular phones. For example, they use YouTube videos to learn new management techniques or how to graft Arabica 
varieties onto Robusta rootstock, a very useful technique to avoid coffee leaf rust, but highly skilled and costly. Once again, this characteristic can be strengthened and aimed specifically at the formation of a new generation of coffee growers with better access to knowledge and information.

However, emigration continues to be a route for improving the family economy, even amongst the younger coffee growers. Seasonal migration to agribusiness fields in the northern states of Mexico or the maquilas of Tijuana prevails among this young population that still insists on producing coffee. This strategy helps the family to continue producing coffee while bringing in extra income. In this strategy, coffee production serves as an anchor at their place of origin.

A variant of this strategy is legal migration to the United States under a temporary employment contract, with a return-trip work visa. The work in these fields is taxing, but as a woman in Unión Juárez told us: "You only have to work there until you can make some good money. During the whole contract you just stay there in the fields working, you don't go out, that's all. It's exhausting, but ... " (C., woman coffee farmer, 53, community of El Desenlace, Unión Juárez, 13 October 2018).

These out-migration flows now overlap with return, voluntary or forced immigration flows. Their presence in our area of study also has varied implications for coffee cultivation.

Regarding forced in-migration, the deportation policy implemented by the Trump administration migrants who left for the U.S. 20 or more years ago are now being forced to return to a land where coffee remains the main economic activity. For those who have been deported, coffee is no longer significant, either economically or professionally. However, for the majority, the only viable option is to return to work the coffee lands that they left in the hands of relatives.

Others decide to return for different reasons (see Mestries 2013) after a long stay in the United States, where they have obtained new professional skills, often relating to gardening, but also in the industrial and commercial sectors. Among the youth who return from the United States, there is a minority that choose to reactivate their parents' coffee parcels, but now seek to bring added value to the production. They have learned about the world of coffee consumption in the north and now want to instill part of that world in their home communities, where cappuccino, macchiato or café latte are not yet part of the coffee-consuming culture. These youth see themselves as entrepreneurs, with better access to knowledge and resources outside the community. They have learned to be baristas and open coffee shops in their home communities, seeking to attract other youth to the region. Their shops become places where young people gather, and they encourage a culture of local coffee consumption in an effort to access the benefits that retail coffee markets in consuming countries obtain from specialty or gourmet coffee establishments.

They also bring new ideas for improving and diversifying coffee-related products and carry out experimental programs relating to agro-ecology, leaf rust management and agro-forestry conservation. For them, migration is no longer an appealing option, because they are deeply committed to coffee production and commercialization. This new brand of coffee grower detaches itself from traditional decision-making spaces like ejido assemblies. The figure of the coffee-growing peasant who inherited the age-old agrarian and ejido struggle is no longer a reference for their identity. Their vision of coffee production is one of a lucrative activity that encompasses everything from growing their own coffee on their family's land to roasting and selling it in their own establishments to creating propriety blends for production. Once again, we might argue that a policy of sustainable coffee and incentives to access regional markets that support these initiatives might open new possibilities for the regional production and sale of coffee, particularly in the Tacaná region, which is a focus of tourism. However, there is no decisive promotion policy in place that targets the new generation and restores the importance of coffee in the region. 
5.4. Coffee Renovation and Remittances for Adapting: Is Out-Migration Maintaining a Much-Depressed Economic Activity, Such as Small-Holder Coffee Farming?

Statistical analyses cannot portray transnational links maintained between those who migrate and those who remain in their places of origin. Organized around family ties, these social relationships in our area of study influence coffee farming in different ways.

During field-work, we have observed that international remittances support a radical—and not gradual-renovation of coffee parcels. The case of B.R. (32 years old), a woman coffee grower (one of the three women interviewed) in the community of Talquián Viejo is a telling example. In one highly risky transaction, she used remittances sent from the United States by her husband to completely eliminate shade on her parcel, where she also introduced hybrid cultivars on all the land, eliminating all traditional varieties. She followed the technical advice of the Rogers Family Company, an international coffee and tea business, which maintains a program of coffee plantation renovation in the zone and encourages the cultivation of sun-grown coffee, supplies inputs and plants for a three-year period and offers technical advice. B.R. hoped to significantly increase her yields, even at the cost of applying agrochemicals to her formerly organic coffee. Her renovation was the most radical of the Talquián community. The rest of the coffee growers (all men) were very critical of her decision but were keeping a close eye on her progress. In our most recent visits (March 2019) we learned that her coffee failed to pass quality standards and was rejected by the regional organic coffee growers' association.

A rather different use of the remittances is that of the Guatemalan families that live simultaneously on both sides of the border, and receive money from family members working in the U.S. These families are buying coffee plots on the Mexican side that have been left untended due to coffee leaf rust. Where some abandon coffee and possibly migrate north, others find niches of opportunity to increase their production with money sent from the same north.

Because of the social land titling on the Mexican side (i.e., ejido land), the community of Unión Juárez-Paso del Norte puts restrictions on trading its land with foreigners. These restrictions can be bypassed easily by purchasing a Mexican birth-certificate in an illegal market of certificates that operates from Unión Juárez and which is an open secret.

The increasing presence of Guatemalans making their homes in the municipality is already triggering negative reactions: Mexican nationals are starting to see Guatemalans as a source of conflict and criminality.

Right now many [Mexican people] are selling their houses and lands, and they [the people from Guatemala], are taking over them because they bring the pay. They say they have money from the United States. If we get stunned, they will take our coffees ... Moreover, even in our homes, they enter; right now they grabbed the wood from here ... . (JM, coffee farmer, 42, Unión Juárez, El Mango section, 11 September 2017).

\subsection{The End of Arabiga Quality Coffee Thanks to Migration as Adaptation? the Robusta Era in Times of Climate Change}

Finally, in the complex picture of interactions between migration, climate change and coffee, another global process takes its particular expression in our area of study: the substitution of traditional Arabica coffee varieties for the rough Robusta (Coffea Canephora) coffee has been accelerated due to a combination of climatic, agricultural and commercial factors and remittances (Bunn et al. 2015).

On the one hand, Robusta's resistance to coffee leaf rust and the increase in temperature that allows its establishment at higher altitudes, previously not suitable for Robusta, offers a solution for some coffee growers to escape the crisis.

In conversations with coffee growers belonging to a social segment of coffee producers that is not particularly interested in the production of quality organic coffee, Robusta seems a plausible alternative to avoid abandonment of coffee plots: "Right now, the only thing that has sustained us for the majority of those that remain (without going to the US) is Robusta. Yes, it is the only one (coffee variety) in 
which there is hope, because the coffee we say, the small coffee, the Bourbon (Arabica variety), is finished." (RJ, 46. Coffee farmer, Unión Juárez, 15 September 2018).

On the other hand, the distribution of seeds and inputs by the Nestle international company-the biggest stockpiler of this coffee variety, which distributes seedlings of cloned Robusta varieties seeking to secure its supply of soluble coffees-facilitates the replacement of Arabicas for Robusta.

Finally, the effect of migration on Robusta's expansion process is also manifested in our study area. In an economic drip effect, part of the remittance flow from migrants residing in the United States is channeled to the purchase of coffee plots in the lower areas of Tacaná Volcano, where Robusta is highly productive, thus contributing to the spread of Robusta varieties. An additional benefit to this strategy is that Robusta production requires less labor and investment. The degree to which remittances have contributed to expanding and reactivating coffee cultivation remains unknown. There are also no data at the scale of our municipalities that allow us to deepen the ownership, demographic and productive changes induced by remittances in this cross-border area.

This whole network of local and international factors (to which should be added the political impulse given to the cultivation of Robusta by the current administration of the president of Mexico, López Obrador), are pushing towards a transformation of the coffee agroforestry systems based on Arabica varieties that have ecological and commercial implications. This has stirred up alarm among some organizations of Arabica coffee growers, who see the expansion of Robusta as a threat to quality shade-grown coffees and to their access to coffee markets differentiated by the quality of the beans (Bunn et al. 2015). Robusta requires less shade-cover and is less heat-sensitive, yields are higher and faster and is more disease-resistant. However, its lower quality traditionally fetches lower prices.

Travelling seeds, intertwined narratives and knowledge, the role and interests of international and governmental actors, long-term and circular migration, intra-regional migration, remittances and deportation policy comprise a complex interactive puzzle that should encourage new ways to conceptualize the nexus of climate change-migration-adaptation.

\section{Conclusions}

In various policy documents on climate change (Rigaud et al. 2018; FAO 2017; Delavelle 2013; Foresight 2011), the notion of migration as a form of adaptation appears undisputed (Black et al. 2011). However, it is rarely combined with an examination of migration policies that promote the closing of borders and the criminalization of migrants (Turhan and Armiero 2017). Similarly, in situ adaptation strategies for coffee are confined to the agronomic and ecosystem sphere (Nalau and Becken 2018) and do not entail a comprehensive assessment that includes political and economic constraints that at different scales may hinder the development of in situ adaptation. Both approaches are sometimes presented as opposing trends on the road to adaptation (Upadhyay and Mohan 2014).

Critical researchers have pointed out that narratives of mainstream adaptation fail to account for the imbalance of power (Felli and Castree 2012) that, for our case, characterized coffee production, and relies on an adaptation conception void of its political content (Bettini 2014; Scoville-Simonds et al. 2019). The coffee-growing landscapes of the transboundary region of Tacaná are an expression of those current imbalances that generate socio-ecological relations that are far from achieving an equitable adaptation (Taylor 2015; Klepp and Chavez-Rodriguez 2018). The global flows of stock market finances, consumer preferences, international biotechnological research and the increasing effects of climate change shape the future of coffee production. In such panorama, however, the burden of adapting amidst restricted possibilities is entirely placed on the coffee farmer's shoulders.

In this paper, we have followed the suggestions of Klepp (2017) for politicizing and denaturalizing the climate change and migration nexus, including in it structural factors and a perspective of justice that is currently absent from dominant narratives and the practice of adaptation. Understanding climate change in the context of an inequitable agricultural commercialization, changes in property regimes, new and old forms of capital accumulation, migratory flows, technological change and the 
emergence of new subjectivities in the rural world can contribute to this reconceptualization of the migration-climate change nexus.

Similarly, addressing migration-adaptation dynamics in context-specific settings without detaching them from the broader migratory processes that are occurring at different scales can also be a way to work towards this aim. The entanglement of processes that happen at different scales has allowed us to highlight the limitation of using labels such as "migration as adaptation" or "adaptation in situ". These labels fail to realize the intrinsically trans-scalar nature of the migration-climate change nexus (Eklund et al. 2016).

At a regional scale, we have highlighted how the interaction between processes that occur at an international scale, such as the reinforcement of United States immigration policies from 2014 onwards in the southern border of Mexico, or the advance of coffee leaf rust across Latin America during 2013 and 2014, alters migration dynamics at the municipal level in an unexpected manner. We have contrasted the narrative of migration as an adaptation with the current situation of reinforcement of border control policies at the Chiapas-Guatemalan border, where thousands of people are trapped, not because of climate hazards but by a securitization approach to migration.

We have taken the renewal of shaded coffee plots attacked by coffee leaf rust as a case study of slow-onset climatic impacts and as an indirect indicator of current climate variability. The attack of the fungus has triggered a series of adaptation strategies in situ, which are linked to the agronomic management of coffee plantations (c.f. Harvey et al. 2018). However, these in situ adaptations will be ineffective if they are not accompanied by measures at other scales, such as policies that offer some protection against the low prices in international markets. We have shown how the price of coffee is the most influencing driver of migration. Likewise, we have presented ethnographic data on the various migratory strategies that intersect in our study territory and affect the financing of adaptation measures in situ at the local level.

In situ adaptation practice focuses exclusively on coffee management actions to adapt to climate variability, emphasizing its biophysical dimension. The isolation of climatic impacts from the broader social and political contexts promotes a depoliticizing view of the nexus between climate change and migration. Policies designed from such an apolitical perspective make recommendations and promote courses of action that do not have regard for the current political scenarios.

Rarely are lines of action established for the promotion of regional markets or marketing strategies that place local producers on a stronger footing to access a highly competitive, restrictive market. International political action does not focus on the transformation of the market power imbalances that characterize the international coffee market, neither in terms of policies for the redistribution of benefits or alternative policies for migration. Can it then be argued that failure to secure prices well above the poverty line results in migration as adaptation?

Beyond a conception of adaptation as a choice between opposites, we suggest attention should focus on the redesign of more integral policies to respond to climate change and its interaction with commercialization and production factors in their multiple manifestations. In this sense, and following Oliver-Smith (2012), the articulation of ecological and social theory can help us to develop a solid understanding of the co-production of society and the environment and to advance adaptation strategies that can be truly effective.

In the policy realm, the main lesson to be learned is that dominant adaptation narratives that are dictating policy guidelines on climate change and migration need to be reformulated to include the harsh realities of today's forms of migration. If we are to promote migration as a form of adaptation, the first step should be towards a complete reformulation of the current migration policy. The question remains whether this is possible in today's world and to what extent this challenges the belief in nation-states as the primary form of political organization on which political boundaries around the world are founded. In the medium term, and with the acceleration of climate impacts, the issue of adaptation will be critical in any policy sector. Therefore, it is worth rethinking new adaptation paradigms that are effective, inclusive and above all defined on principles of social and economic justice. 
Author Contributions: Conceptualization, C.R.-d.-O.; Data curation, P.R.-C. and Y.M.-U.; Formal analysis, C.R.-d.-O., P.R.-C. and Y.M.-U.; Investigation, C.R.-d.-O.; Methodology, C.R.-d.-O.; Visualization, Y.M.-U.; Writing—original draft, C.R.-d.-O.; Writing—review \& editing, C.R.-d.-O.

Funding: This research received no external funding

Conflicts of Interest: The authors declare no conflict of interest.

\section{References}

Avelino, Jacques, Marco Cristancho, Selena Georgiou, Pablo Imbach, Lorena Aguilar, Gustavo Bornemann, Peter Läderach, Francisco Anzueto, Allan J. Hruska, and Carmen Morales. 2015. The Coffee Rust Crises in Colombia and Central America (2008-2013): Impacts, Plausible Causes and Proposed Solutions. Food Security 7: 303-21. [CrossRef]

Bardsley, Douglas K., and Graeme J. Hugo. 2010. Migration and Climate Change: Examining Thresholds of Change to Guide Effective Adaptation Decision-Making. Population Environment 32: 238-62. [CrossRef]

Bebber, Daniel P., Ángela Delgado Castillo, and Gurr Sarah J. 2016. Modelling Coffee Leaf Rust Risk in Colombia with Climate Reanalysis Data. Philosophical Transactions of the Royal Society B: Biological Sciences 371: 20150458. [CrossRef] [PubMed]

Bell, Anne. 2013. A narrative approach to research. Canadian Journal of Environmental Education 8: 95-110.

Bettini, Giovanni. 2014. Climate Migration as an Adaption Strategy: De-Securitizing Climate-Induced Migration or Making the Unruly Governable? Critical Studies on Security 2: 180-95. [CrossRef]

Bettini, Giovanni. 2017. Archaeologies of the Future. In Environmental History of Modern Migrations. Edited by Marco Armiero and Richard Tucker. London and New York: Routledge, pp. 191-205.

Bigo, Didier. 2002. Security and Immigration: Toward a Critique of the Governmentality of Unease. Alternatives 27: 63-92. [CrossRef]

Black, Richard, Stephen R. G. Bennett, Sandy M. Thomas, and John R. Beddington. 2011. Migration as Adaptation. Nature 478: 447-49. [CrossRef]

Blitzer, Jonathan. 2019. How Climate Change Is Fuelling the U.S. Border Crisis|The New Yorker. The New Yorker. April 3. Dispach. Available online: https://www.newyorker.com/news/dispatch/how-climate-change-isfuelling-the-us-border-crisis (accessed on 13 June 2019).

Bunn, Christian, Peter Läderach, Oriana Ovalle Rivera, and Dieter Kirschke. 2015. A Bitter Cup: Climate Change Profile of Global Production of Arabica and Robusta Coffee. Climatic Change 129: 89-101. [CrossRef]

Canet Brenes, Guillermo, Carlos Soto Vízquez, Patricia Ocampo Thomason, Javier Rivera Ramírez, Alejandra Navarra Hurtado, Guadalupe M. Guatemala Morales, and Socorro Villanueva Rodríguez. 2016. La Situación y Tendencias de La Producción de Café En América Latina y El Caribe. San José: Instituto Interamericano de Ciencias Agrícolas (IICAA). Centro Agronómico Tropical de Investigación y Enseñanza (CATIE).

Castañeda, Alejandra. 2016. ¿Qué Es El Programa Frontera Sur? Boletín 1. Observatorio de Legislación y Política Migratoria. Available online: http://observatoriocolef.org/wp-content/uploads/2016/06/BOLET\%C3\%8DN-1Alejandra-Casta\%C3\%B1eda.pdf (accessed on 18 February 2019).

CCAFS. 2015. CGIAR Research Program on Climate Change, Agriculture and Food Security. Available online: https://ccafs.cgiar.org/honduras (accessed on 22 October 2019).

CEPAL (Comisión Económica para América Latina y el Caribe). 2019. Hacia un nuevo estilo de desarrollo. Plan de Desarrollo Integral El Salvador-Guatemala-Honduras-México. Ciudad de México: Diagnóstico, áreas de Oportunidad y Recomendaciones' CEPAL (LC/MEX/TS.2019/6).

Chain-Guadarrama, Adina. 2019. Uso de prácticas de Adaptación basada en Ecosistemas por pequeños cafetaleros en Centroamérica. Agronomía Mesoamericana 30: 1-18. [CrossRef]

COLEF, INM, CONAPO, STPS y SRE. 2016a. Encuesta sobre Migración en la Frontera SUR (EMIF Sur). Tabulados de la serie histórica 2004-2016. Migrantes procedentes de Guatemala a México, vía terrestre. 2004 a 2016, Data bases. El Colegio de la Frontera Norte, Instituto Nacional de Migración, Consejo Nacional de Población, Secretaría del Trabajo y Previsión Social y Secretaría de Relaciones Exteriores, México. Available online: https://www.colef.mx/emif/tabuladossur.php (accessed on 25 February 2019). 
COLEF, INM, CONAPO, STPS y SRE. 2016b. Encuesta sobre Migración en la Frontera NORTE (EMIF NORTE). Tabulados de la serie anualizada 1995-2016. Migrantes procedentes del sur. Data Bases. El Colegio de la Frontera Norte, Instituto Nacional de Migración, Consejo Nacional de Población, Secretaría del Trabajo y Previsión Social y Secretaría de Relaciones Exteriores, México. Available online: https://www.colef.mx/emif/ tabuladossur.php (accessed on 25 February 2019).

Creswell, John W. 2013. Qualitative Inquiry and Research Design: Choosing among Five Approaches. Los Angeles: SAGE Publications.

Eklund, Lina, Clemens Romankiewicz, and Martin Brandt. 2016. Data and Methods in the Environment-Migration Nexus: A Scale Perspective. Die Erde 147: 139-52. [CrossRef]

Delavelle, Fanny. 2013. Climate Induced Migration and Displacement in Mesoamerica. Discussion Paper. London: The Nansen Initiative.

CEPAL (Comisión Económica para América Latina y el Caribe). 2018. Atlas de la migración en los países del norte de Centroamérica (LC/PUB.2018/23), Santiago, Mexico. Available online: https://repositorio.cepal.org/ bitstream/handle/11362/44292/1/S1801072_es.pdf (accessed on 12 September 2019).

FAO (Food and Agriculture Organization). 2017. Migration, Agriculture and Climate Change. Reducing Vulnerabilities and Enhancing Resilience. Report I8297EN/1/12.17. Rome: FAO, 20p.

Felgentreff, Carsten, and Andreas Plott. 2016. Climatic Turn in Migration Studies? Geographical Perspectives on the Relationship between Climate and Migration. DIE ERDE Journal of the Geographical Society of Berlin 147: 73-80.

Felli, Romain. 2013. Managing Climate Insecurity by Ensuring Continuous Capital Accumulation: “Climate Refugees" and "Climate Migrants". New Political Economy 18: 337-63. [CrossRef]

Felli, Romain, and Noel Castree. 2012. Neoliberalising Adaptation to Environmental Change: Foresight or Foreclosure? Environment and Planning A 44: 1-4. [CrossRef]

FIRA (Fideicomisos Instituidos en Relación con la Agricultura). 2016. Panorama Alimentario, café 2016. Available online: https://www.gob.mx/cms/uploads/attachment/file/200636/Panorama_Agroalimentario_Caf_2016. pdf (accessed on 14 December 2018).

Foresight. 2011. Migration and Global Environmental Change: Final Project Report; London: The Government Office for Science.

Frank, Elisa, Hallie Eakin, and David López-Carr. 2011. Social Identity, Perception and Motivation in Adaptation to Climate Risk in the Coffee Sector of Chiapas, Mexico. Global Environmental Change 21: 66-76. [CrossRef]

Gay, C., F. Estrada, C. Conde, H. Eakin, and L. Villers. 2006. Potential Impacts of Climate Change on Agriculture: A Case of Study of Coffee Production in Veracruz, Mexico. Climatic Change 79: 259-88. [CrossRef]

Geddes, Andrew, and Andrew Jordan. 2012. Migration as Adaptation? Exploring the Scope for Coordinating Environmental and Migration Policies in the European Union. Environment and Planning C Government and Policy 30: 1029-44. [CrossRef]

Gemenne, François, and y Julia Blocher. 2017. How can migration serve adaptation to climate change? Challenges to fleshing out a policy ideal. Geographical Journal 183: 336-47. [CrossRef]

Glaser, Barney G, and Anselm L Strauss. 1967. The Discovery of Grounded Theory: Strategies for Qualitative Research. Chicago: Aldine Publishing.

Götz, Schroth, Peter Laderach, Jan Dempewolf, Stacy Philpott, Jeremy Haggar, Hallie Eakin, Teresa Castillejos, Jaime Garcia Moreno, Lorena Soto Pinto, Ricardo Hernandez, and et al. 2009. Towards a Climate Change Adaptation Strategy for Coffee Communities and Ecosystems in the Sierra Madre de Chiapas, Mexico. Mitigation and Adaptation Strategies for Global Change 14: 605. [CrossRef]

Gustin, Georgina, and Mariana Henninger. 2019. Climate Change Is Devastating Central America, Driving Migrants to the U.S. Border. NBC News. July 9. Inside Climate News. Available online: https://www.nbcnews. com/news/latino/central-america-drying-farmers-face-choice-pray-rain-or-leave-n1027346 (accessed on 12 July 2019).

Hannah, Lee, Camila I. Donatti, Celia A. Harvey, Eric Alfaro, Daniel Andres Rodriguez, Claudia Bouroncle, Edwin Castellanos, Freddy Diaz, Emily Fung, Hugo G. Hidalgo, and et al. 2017. Regional Modeling of Climate Change Impacts on Smallholder Agriculture and Ecosystems in Central America. Climatic Change 141: 29-45. [CrossRef]

Hartmann, Betsy. 2010. Rethinking Climate Refugees and Climate Conflict: Rhetoric, Reality and the Politics of Policy Discourse. Journal of International Development 22: 233-46. [CrossRef] 
Harvey, Celia A., Milagro Saborio-Rodríguez, M. Ruth Martinez-Rodríguez, Barbara Viguera, Adina Chain-Guadarrama, Raffaele Vignola, and Francisco Alpizar. 2018. Climate Change Impacts and Adaptation among Smallholder Farmers in Central America. Agriculture Food Security 7: 57. [CrossRef]

Henderson, Thomas Paul. 2017. La Reestructuración de Los Sectores Del Café y El Cacao En México y Ecuador. Control Agroempresarial de La Tierra y Trabajo Campesino. LiminaR. Estudios Sociales y Humanísticos 15: 128-141. [CrossRef]

Hernández-Gutiérrez, José Carlos, and Ronald Sáenz. 2018. La Securitización Del Fenómeno Migratorio En El Caso Del Programa Frontera Sur. GESI, International Security Studies Group 19: 12.

Huq, Saleemul. 2013. Adapting to Climate Change: A Challenge and Opportunity. World Resources Institute. Available online: https://www.wri.org/our-work/project/world-resources-report/adapting-climate-changechallenge-and-opportunity (accessed on 23 October 2019).

Imbach, Pablo, Megan Beardsley, Claudia Bouroncle, Claudia Medellin, Peter Läderach, Hugo Hidalgo, Eric Alfaro, Jacob Van Etten, Robert Allan, Debbie Hemming, and et al. 2017. Climate Change, Ecosystems and Smallholder Agriculture in Central America: An Introduction to the Special Issue. Climatic Change 141: 1-12. [CrossRef]

INCAFECH. 2019. El Café En México. Instituto Nacional del Café Chiapas. Gobierno del Estado de Chiapas. Available online: https://www.incafech.gob.mx/ (accessed on 27 October 2019).

INEGI (Instituto Nacional de Estadística. 2014. INEGI (Instituto Nacional de Estadística, Geografía e Informática). 2014. ENADID (Encuesta Nacional de la Dinámica Demográfica). 2014. Tabulados básicos. Available online: https://www.inegi.org.mx/programas/enadid/2014/default.html (accessed on 28 February 2019).

INEGI (Instituto Nacional de Estadística). 2015. INEGI (Instituto Nacional de Estadística, Geografía e Informática). 2015. Censos de población y vivienda 1990, 1995, 2000, 2010 y Encuesta Intercensal 2015. Bases de datos. Instituto Nacional de Estadística Geografía e Informática. Gobierno de México. Available online: https://www.inegi.org.mx/app/areasgeograficas/?ag=07 (accessed on 28 February 2019).

INEGI (Instituto Nacional de Estadística. 2019. INEGI (Instituto Nacional de Estadística, Geografía e Informática). 2019. Calculadora de inflación. Inflación de enero de 2003 a diciembre de 2017. Available online: https://www.inegi.org.mx/sistemas/indiceprecios/CalculadoraInflacion.aspx (accessed on 28 February 2019).

Isacson, Adam, Maureen Meyer, and Gabriela Morales. 2014. Mexico's Other Border: Security, Migration, and the Humanitarian Crisis at the Line with Central America. Washington Office on Latin America-WOLA-. Available online: https://www.wola.org/wp-content/uploads/2014/06/Mexicos-OtherBorder-PDF.pdf (accessed on 15 August 2019).

Klepp, Silja. 2017. Climate Change and Migration. Oxford Research Encyclopedia of Climate Science 1: 1-37. [CrossRef]

Klepp, Silja, and Libertad Chavez-Rodriguez. 2018. Governing Climate Change. The Power of Adaptation Discourses, Policies, and Practices. In A Critical Approach to Climate Change Adaptation. DIscourses, Policies, and Practices. Edited by Silja Klepp and Libertad Chavez-Rodriguez. Routledge Advances in Climate Change Research. London and New York: Routledge Earthscan, pp. 3-34.

Lejtreger, Raquel. 2019. 'La Movilidad Humana En La Agenda Climática de Las Américas: Necesidades y Oportunidades'. San José, C.R.: Organización Internacional para las Migraciónes (OIM). Oficina regional para Centroamérica. Available online: https://publications.iom.int/books/la-movilidad-humana-en-la-agendaclimatica-de-las-americas-necesidades-y-oportunidades (accessed on 28 October 2019).

Markham, Lauren. 2019. Climate Change Is Pushing Central American Migrants to the USLauren Markham. The Guardian. April 6. Available online: https:/www.theguardian.com/commentisfree/2019/apr/06/us-mexicoimmigration-climate-change-migration (accessed on 14 August 2019).

McCook, Stuart, and John Vandermeer. 2015. The Big Rust and the Red Queen: Long-Term Perspectives on Coffee Rust Research. Phytopathology 105: 1164-73. [CrossRef]

McNamara, Karen Elizabeth, and Lisa Buggy. 2017. Community-Based Climate Change Adaptation: A Review of Academic Literature. Local Environment 22: 443-60. [CrossRef]

Merlín-Uribe, Yair, Fabien Charbonnier, Armando Contreras-Hernández, Obeimar Balente Herrera Hernández, Lorena Soto-Pinto, Yair Merlín-Uribe, Fabien Charbonnier, Armando Contreras-Hernández, Obeimar Balente Herrera Hernández, and Lorena Soto-Pinto. 2018. Tipología de Estrategias Campesinas En La Caficultura Orgánica de La Sierra Madre de Chiapas. Ecosistemas y Recursos Agropecuarios 5: 411-23. [CrossRef]

Mestries, Francis. 2013. Los Migrantes de Retorno Ante Un Futuro Incierto. Sociológica 28: 171-212. 
Milman, Oliver, Emily Holden, and David Agren. 2018. The Unseen Driver behind the Migrant Caravan: Climate Change. The Guardian, October 30.

Méndez Espinoza, José Arturo, Néstor Estrella Chulím, and Javier Ramírez Juárez. 2006. El programa moscamed en la región fronteriza México-Guatemala: algunos factores asociados a su evolución y permanencia. $R a$ Ximhai, 435-48. [CrossRef]

Nalau, Johanna, and Susanne Becken. 2018. Ecosystem-Based Adaptation to Climate Change: Review of Concepts. Research Report 15. Queensland: Griffith Institute for Tourism, Griffith University.

Neumann, Kathleen, and Henk Hilderink. 2015. Opportunities and Challenges for Investigating the Environment-Migration Nexus. Human Ecology 43: 309-22. [CrossRef] [PubMed]

Newland, Kathleen. 2019. The Global Compact for Safe, Orderly and Regular Migration: An Unlikely Achievement. International Journal of Refugee Law 30: 657-60. [CrossRef]

Oliver-Smith, Anthony. 2012. Debating Environmental Migration: Society, Nature and Population Displacement in Climate Change. Journal of International Development 24: 1058-70. [CrossRef]

Piguet, Etienne, Antoine Pécoud, and Paul de Guchtenerire. 2011. Migración y Cambio Climático. Madrid: Publicación Del Instituto Universitario de Estudios Sobre Migraciones, pp. 161-96.

Presidencia, Gobierno de Honduras. 2018. En La Cumbre Iberoamericana: Presidente Hernández Llama a Integrar Un Bloque En Defensa de Precios Justos Del Café. November 18. Available online: https://www.presidencia.gob.hn/index.php/gob/el-presidente/4995-en-la-cumbre-iberoamericanapresidente-hernandez-llama-a-integrar-un-bloque-en-defensa-de-precios-justos-del-cafe (accessed on 22 October 2019).

Renard, Marie-Christine, and Mariana Ortega Breña. 2010. The Mexican Coffee Crisis. Latin American Perspectives 37: 21-33. [CrossRef]

Renard, Marie-Christine, and Rosa María Larroa Torres. 2017. Política pública y sustentabilidad de los territorios cafetaleros en tiempos de roya: Chiapas y Veracruz. Estudios Latinoamericanos 40: 95-113. [CrossRef]

Ribando Seelke, Clare, and Carla Davis-Castro. 2019. Mexico's Immigration Control Efforts. CRS In Focus IF10215. Congressional Research Service. Available online: www.crs.gov (accessed on 12 February 2019).

Riessman, Catherine Kohler. 2008. Narrative Methods for the Human Sciences. London: SAGE.

Rigaud, Kanta Kumari, Alex de Sherbinin, Bryan Jones, Jonas Bergmann, Viviane Clement, Kayly Ober, Jacob Schewe, Susana Adamo, Brent McCusker, Silke Heuser, and et al. 2018. Groundswell: Preparing for Internal Climate Migration. Washington: World Bank. [CrossRef]

Sach, Jeffrey, Kaitlin Y. Cordes, James Rising, Perrine Toledano, and Nicolas Maennling. 2019. Ensuring Economic Viability and Sustainability of Coffee Production. New York: Columbia Center on Sustainable Investment. Columbia University.

Semple, Kirk. 2019. Central American Farmers Head to the U.S., Fleeing Climate Change. The New York Times. April 13. World. Available online: https://www.nytimes.com/2019/04/13/world/americas/coffee-climatechange-migration.html (accessed on 17 October 2019).

Ruiz Meza, Laura Elena. 2010. Climate Change, Poverty and Migration Processes in Chiapas, Mexico. Climate Change and Labour: The Need for a "Just Transition": International Journal of Labour Research 2: 187-210. [CrossRef]

Ruiz Meza, Laura Elena. 2015. Adaptive Capacity of Small-Scale Coffee Farmers to Climate Change Impacts in the Soconusco Region of Chiapas, Mexico. Climate and Development 7: 100-9. [CrossRef]

Scientific Software Development GmbH. 2018. ATLAS.Ti MAC 8. version 8.4. Berlin: Scientific Software Development $\mathrm{GmbH}$.

Scoville-Simonds, Morgan, Hameed Jamali, and Marc Hufty. 2019. The Hazards of Mainstreaming: Climate Change Adaptation Politics in Three Dimensions. World Development 125: 104683. [CrossRef]

SIAP. 2015. Anuario Estadístico de la Producción Agrícola. 2003-2015. Servicio de Información Agroalimentaria y pesquera. Secretaria de Agricultura y Desarrollo Rural. Gobierno de México. Data Bases. Available online: https://nube.siap.gob.mx/cierreagricola/ (accessed on 26 February 2019).

Sward, Jon, and Samuel Nii Ardey Codjoe. 2012. Human Mobility and Climate Change Adaptation Policy: A Review of Migration in National Adaptation Programmes of Action (NAPAs). Available online: http: //ugspace.ug.edu.gh/handle/123456789/1969 (accessed on 15 October 2019). 
Tacoli, Cecilia. 2009. Crisis or Adaptation? Migration and Climate Change in a Context of High Mobility. In Population Dynamics and Climate Change. Edited by J.M. Guzmán, G. Martine, Gordon McGranahan, D. Schensul and Cecilia Tacoli. New York and London: UNFPA, New York and London: IIED, pp. 104-18.

Taylor, Marcus. 2015. The Political Ecology of Climate Change Adaptation: Livelihoods, Agrarian Change and the Conflicts of Development. New York: Routledge.

Toniutti, Lucile. n.d. Breeding for the Future. World Coffee Reseach. Available online: https://worldcoffeeresearch. org/work/breeding-future/ (accessed on 27 October 2019).

Torre Cantalapiedra, Eduardo, and José Carlos Yee Quintero. 2018. México ¿una Frontera Vertical? Políticas de Control Del Tránsito Migratorio Irregular y Sus Resultados, 2007-2016. LiminaR. Estudios Sociales y Humanísticos 16: 87-104. [CrossRef]

Turhan, Ethemcan, and Marco Armiero. 2017. Cutting the Fence, Sabotaging the Border: Migration as a Revolutionary Practice. Capitalism Nature Socialism 28: 1-9. [CrossRef]

Upadhyay, Himani, and Divya Mohan. 2014. Migrating to Adapt? Contesting Dominant Narratives of Migration and Climate Change. Discussion Paper. New Delhi: The Energy and Resources Insititute.

Valero Martínez, Mario. 2016. Visión geopolítica e histórica de la fronteras de Venezuela y Guyana. Revista Geopolitica 7: 112-2.

Varela Huerta, Amarela. 2015. La Securitización de La Gubernamentalidad Migratoria Mediante La Externalización de Las Fronteras Estadounidenses a Mesoamérica. Revista Contemporánea 2: 15.

Villafuerte, Daniel, and Maria del Carmen Aguilar. 2006. Crisis Rural y Migraciones En Chiapas. Migración y Desarrollo 6: 102-30.

World Coffee Research. n.d. Next-Generation F1 Hybrid Varieties. World Coffee Research. Available online: https://worldcoffeeresearch.org/work/next-generation-f1-hybrids/ (accessed on 20 October 2019).

ELCOLEF. 2018. Cronología de La Caravana Centroamericana'. Observatorio de Legislación Migratoria. Available online: http://observatoriocolef.org/infograficos/cronologia-de-la-caravana-centroamericana/ (accessed on 19 February 2019).

(C) 2019 by the authors. Licensee MDPI, Basel, Switzerland. This article is an open access article distributed under the terms and conditions of the Creative Commons Attribution (CC BY) license (http://creativecommons.org/licenses/by/4.0/). 